\title{
PEDAGOGY
}

\section{School historical education in Ukraine in the post-Soviet period}

\author{
Yu. P. Antybura \\ Bogdan Khmelnytsky Melitopol State Pedagogical University, Melitopol city, Ukraine \\ Corresponding author. E-mail: julia.ant87@gmail.com \\ Paper received 21.01.20; Accepted for publication 04.02.20.
}

https://doi.org/10.31174/SEND-PP2020-219VIII87-01

\begin{abstract}
The paper carries out retrospective review of school historical education of Ukraine within the period starting since 1991. Six stages of the formation and development of school historical education were separated and the outstanding characteristics of every stage were identified. The amendments in the curriculums and history textbooks within the specified period were analyzed. The emphasis was placed on the fundamentally new approaches to the composition of curriculums. The importance of the historical education for education of a citizen whose consciousness could be hardly manipulated through misrepresentation of historical facts was made actual.
\end{abstract}

Keywords: school historical education, general secondary education establishment, curriculums, textbooks.

Introduction. School historical education has a direct influence on the formation of national identity of citizens of a certain country. The analytical report «The policy of historical memory within the context of the national security of Ukraine» defines the national identity as a multicomponent formation including the most significant elements such as the national consciousness, way of thinking, historical memory, national traditions, ethno-national characters, myths, beliefs of the citizens about the place of the country in the world and its civilizational belonging [7, p. 13]. The issue of the national identity is particularly important in ex-USSR countries, taking into account the necessity to build the political nation under the conditions of the independence and sovereignty. According to the historian H. Kasianov, the public demand for sovereignization of the past emerged already in the latter half of the eighties of twenties century, within the period of Soviet system destabilization, and this became the process of national self-determination of history and historical memory in Soviet Republics [4, p. 205]. These processes were activated after the fall of the Union of Soviet Socialist Republics. Such amendments dealt mostly with the school curriculums and history textbooks.

In our view, the amendments of the paradigm of school historical education may be traced especially through the example of Ukraine.

Literature Review. Such scientists as O. Pometun, K. Bakhanov, O. Tomachenko, Ya. Hrytsak, S. Kulchytskyi, V. Smolii, F. Turchenko, O. Udod and others stand out from the researchers who dealt with the problems of the formation and development of school historical education of ex-USSR countries and Ukraine.

So, O. Pometun investigates the problems of the development of school historical education in the twentieth century. The researcher defines an objective of history teaching at the stage of the formation of Ukrainian nationhood as the formation of national consciousness and way of thinking. The range of her academic interests includes the school history textbook and the development of critical thinking of pupils by means of history. The textbooks and history curriculums were researched in detail by K. Bakhanov, S. Kulchytskyi and F. Turchenko. Ya. Hrytsak dealt with the problems of history teaching after the fall of the USSR. The historian O. Udod considered the axiological approach during formation of content of the modern school historical education. The researcher O. Tomachenko studied the Ukrainian policy in the field of school historical education within the period from attainment of independence to the year of 2009.

The papers of these and other pedagogical scientists are one of the sources for study and generalization of the development of school historical education of Ukraine.

Purpose. To investigate the school historical education in Ukraine in the post-Soviet period, to identify the stages of its formation and development.

Materials and methods. The range of general and partial methods of historical and pedagogical research was used for the achievement of the purpose in view. The general methods include the historical and structural method which enabled to identify the stages of the formation and development of school historical education. The constructive and genetic method enabled to trace the amendments in the content of school historical education in general, to establish periodization of the problem being investigated. The historical and comparative method enabled to correlate and to compare the stages identified. The partial methods of the historical and pedagogical research included the axiological (for identification of values), the modernizing (for study of amendments and reforms) and the paradigm methods etc.

The curriculums and the conceptions of the history curriculums for comprehensive secondary schools of Ukraine within the period between years 1991 and 2019, the legislative acts as for the education policy of Ukraine, documents from the funds of the Central State Archives of Supreme Authorities and Governments of Ukraine, as well as the researches of the prominent Ukrainian teachers and historians were used as the materials for the paper.

Results and their discussion. The Ukrainian history was considered as a part of the Soviet Union history, and was taught on the basis of the concept of socio-economic formations and class struggle during the stay of Ukraine in the Union of Soviet Socialist Republics. The historian F. Turchenko notes that «the history of Ukraine in the schools of the republic was presented in the non-system manner - as an additional local material intended to illus- 
trate all-Union tendencies» $[10$, p. 6]. No wonder that the school history education required immediate reform after the fall of the USSR.

The school historical education includes such components as educational courses - history of Ukraine, world history, regional history (of the native land); training programs and textbooks; methodological support, etc. Let us dwell more on the content of the curriculums and textbooks, because they are the most complete reflection of the changes that took place in education after the fall of the USSR.

We propose to consider the changes that have taken place, in stages for a more structured overview of school history education and Ukraine since 1991. Each of these stages is characterized not only by update of the curriculums, but also by the fundamentally new approaches to their composition.

The researcher of contemporary school historical education K. Bakhanov identifies three stages of the fundamental changes in its content:

- 1989-1992: separation of the history of Ukraine as an independent course, the occurrence of new approaches to the presentation and definition of the essence of individual periods, increasing attention to the role of the individual in history, raising the question of alternativeness in history and the need to focus on dialogue with a pupil.

The history course of the Ukrainian SSR was introduced in schools as an independent subject in 1989-1990 academic years. The pupils had to study this course from the eighth grade and in parallel with the course of the history of the USSR. The explanatory note to the draft curriculum stated that the task of teaching the history of the USSR was determined by the policy of re-formation and the complex process of abandoning dogmatism and stereotypes that dominated over the consciousness of several generations of the Soviet people. Liberation from the «white spots» of history was proclaimed. The repressions against the Ukrainian peasants during the period of collectivization were considered and condemned in the school for the first time; the famine of 1932-1933 in Ukraine was estimated [11, p. 4].

The textbook on the history of Ukraine for 10-11 grades of secondary schools was published in 1991. As F. Turchenko notes, the textbook is based on the theoretical foundations of the Soviet historiography. Among other things, it describes the "prominent role of the Bolsheviks in the First Russian Revolution in Ukraine». However, there are already references to the UPA (Ukrainian Insurgent Army) and it establishes the fact that the Ukrainian SSR «finally lost the remnants of sovereignty» as a result of the formation of the Soviet Union, like other national republics [10, p. 12-13].

- 1992-1996: the departure from the old cliches and stereotypes related to the formational approach was proclaimed, the civilization development of mankind was emphasized, the cultural orientation of the content was strengthened, the research and search skills were introduced.

The memorandum of the collegiate organ of the Ministry of Public Education of Ukraine on the beginning of the new 1991-1992 academic year refers, in particular, to the first lesson for all secondary schools on the topic «My land is my live history». It is noted that teachers have widely used the historical acts adopted by the Verkhovna Rada of Ukraine. Particular attention was paid to the resolution of the Verkhovna Rada of the USSR as of August 24, 1991 «On the Declaration of Independence of Ukraine» [12, p. 14]. Choosing such a topic for the first lesson is indicative of a focus on the new national values, supported by the Ministry of Public Education of Ukraine, beginning with the first academic year after the declaration of Ukraine's independence.

The researcher K. Bahanov notes that the first generation of Ukrainian textbooks, which were created within 1991 - 1995, oriented pupils to the acquisition of historical knowledge, motivating this to understand the presentday problems or stipulating a civic position and a sense of patriotism [1, p. 22].

- 1996-2005: separation of the world history curriculum from the curriculum of the history of Ukraine, transition to a 12-year study period and introduction of the 12-point system for assessment of pupils' academic achievements [2, p. 13].

F. Turchenko states that it was in the mid-1990s when Ukraine became the first among the post-Soviet republics which received a complete set of textbooks on the national history for comprehensive schools. Although these textbooks had drawbacks: overload of the factual material, academic style of information presentation, etc. [10, p. 65]. We consider that this is a consequence of the shortest possible term of preparation of textbooks.

The historian $\mathrm{O}$. Tomachenko identifies the fourth stage of update of the content of school historical education:

- 2005-2009, when the curriculum for the 12-year school was adopted, and history was taught according to this curriculum until the end of the 2009-2010 academic year inclusively [9, p. 11].

Today we can already talk about the following stages of transformation of scientific and methodological support of school historical education:

\section{- 2009-2016 years.}

The Resolution of the Verkhovna Rada of Ukraine dd. July 6, 2010 No. 2442-VI «On the introduction of amendments to the legislative acts on the issues of the general secondary and pre-school education as for the arrangement of teaching and educational process» cancelled 12-years period of study [3]. It made necessary to compose new curriculums and to publish new textbooks.

In 2012, the Ministry of Education and Science of Ukraine prepared a new version of the history curriculum for secondary schools, which declared a significant unloading of the content of all courses due to the refusal from detailed elaboration and formation of more balanced structure. The number of hours compared to the previous version of the curriculum remained unchanged. However, the curriculum itself has undergone significant changes. For the first time, it included the practical classes that provide the independent work of pupils with historical sources. The curriculum was composed on a combination of personally oriented, activity and competency-based approaches to learning [5, p. 4].

The history course for the 5th grade «Introduction to history. The propedeutical course» suffered the greatest changes in the curriculum of 2012, so let's dwell on it. 
One of the main objectives of the course was «the formation of pupils' ideas and initial knowledge of history as a field of human knowledge, as a science that has its own subject of study and its methods of research». Therefore, the authors placed a main emphasis not on the presentation of actual historical material, but on the development of pupils' interest in the subject and motivation to study it [5, p. 7]. The course syllabus is designed for 35 hours per year, with 3 lessons for subject-based assessment, 1 course summary lesson and 1 reserve lesson. The course consists of three sections: "Where and how the historians learn about the past», «What and who history tells about», «Which monuments are the parts of history».

In 2015 , the curriculum was unloaded by forming a specified list of requirements for pupils' academic achievements, focusing on key events and processes of the epoch, training courses; a balanced structure of all training courses; strengthening of national, general educational and cultural orientation of the educational process [6, p. 3].

\section{- 2016-2019 years.}

The updated curriculum was composed in 2017 in order to implement the Concept of State Policy Implementation in the Field of Reforming General Secondary Education «New Ukrainian School» for the period up to 2029, and in order to modernize its curriculums based on the competent approach [8, p. 7].

The program does not divide lessons according to sections, clearly defined subjects and the number of practical classes. The teacher is given the freedom to determine the name of the topic of the lesson and the number of hours to study it.

The purpose of school historical education is determined by the formation of a free personality who recognizes universal human and national values; education of civic consciousness; cultivation of tolerance, ability to gain understanding with other people in order to achieve socially important goals [8, p. 9].

The structure of the propedeutical course for the 5th grade «Introduction to history» has changed significantly; it has six sections already: "What is history», "Countdown in history», «Where history takes place», «Sources for the study of history», «History of Ukraine in Artifacts», «History researchers», «Everything has a past».

Table 1. Structure of the course curriculums «Introduction to history» for the 5 th grade

\begin{tabular}{|c|c|c|c|}
\hline $\begin{array}{c}\text { Structural compo- } \\
\text { nents }\end{array}$ & $\begin{array}{c}\text { Curriculum } \\
\text { in 2005 }\end{array}$ & $\begin{array}{c}\text { Curriculum } \\
\text { in 2013 }\end{array}$ & $\begin{array}{c}\text { Curriculum } \\
\text { in 2017 }\end{array}$ \\
\hline $\begin{array}{c}\text { Number of hours } \\
\text { per year }\end{array}$ & 35 & 35 & 35 \\
\hline $\begin{array}{c}\text { Number of subjects } \\
\text { per subject }\end{array}$ & $\begin{array}{c}\text { It is deter- } \\
\text { mined for } \\
\text { each subject }\end{array}$ & $\begin{array}{c}\text { It is deter- } \\
\text { mined for } \\
\text { each subject }\end{array}$ & $\begin{array}{c}\text { There is no } \\
\text { distribution } \\
\text { of hours in } \\
\text { subject }\end{array}$ \\
\hline Practical work & N/A & $\begin{array}{c}5 \text { practical } \\
\text { lessons }\end{array}$ & $\begin{array}{c}\text { Typical tasks } \\
\text { for practical } \\
\text { and creative } \\
\text { works }\end{array}$ \\
\hline $\begin{array}{c}\text { Interdisciplinary } \\
\text { relations }\end{array}$ & $\begin{array}{c}\text { It is not } \\
\text { identified }\end{array}$ & $\begin{array}{c}\text { It is not } \\
\text { identified }\end{array}$ & $\begin{array}{c}\text { It is identi- } \\
\text { fied separate- } \\
\text { ly after sub- } \\
\text { jects 2-6 }\end{array}$ \\
\hline
\end{tabular}

Let's examine the structure of the updated curriculum and compare it with the curriculums in previous editions. This comparison will enable to identify curriculum innovations more clearly.

It is evident that the curriculum of 2017 provides a teacher with greater opportunities for independent determination of the content of academic work according to the national and local context, for choice of the forms and methods of work.

The integrated course «History: Ukraine and the world», being fundamentally new for the Ukrainian school, was composed according to the order of the Ministry of Education and Science of Ukraine dd. February 24, 2017, No. 310 «On the development of curriculums for senior school»; this course does not separate Ukraine from world events, but interprets as a part of world cultural, economical and political space. The problematics of the history of Ukraine makes two thirds of subject matter of the curriculum. It was included into the world, in particular, European historical context and it was shown how this context was created at the same time. The curriculum pays attention to the kinds of learning activity enabling pupils to work individually with the historical information, in particular, proposes the typical lists of subjects for practical lessons, essay writing and project implementation. It is provided that the pupils will be able to acquire the historical and subject competence, in particular, the ability to specify the reasons, essence and consequences of the events, phenomena and processes of $\mathrm{XX}$ and the beginning of XXI century within the territory of Ukraine and other countries, to characterize and to compare, to express own opinion in a well-argued manner [8, p. 75]. We consider this course to be reasonable and well-timed due to the fact that it is important to identify and to show the place of Ukraine in the world space right now.

The work on the update of content of school historical education is carried on; the update of curriculums for 8-9 grades and publishing of new history textbooks for 7-8 grades is expected. Such amendments comply with the time challenges and the necessity of deep history rethinking.

Conclusions. So, we can say about six stages of the formation and development of school historical education: 1989-1992, 1992-1996, 1996-2005, 2005-2009, 20092016, 2016-2019. Each of these stages is characterized by the update of curriculums, replacement of textbooks and fundamentally new approaches to the methodology of history teaching. However, the content of the historical education in Ukrainian schools requires further update in order to overcome old stereotypes related to the formational approach to history study, to integrate the national history into common-European processes harmoniously, to reconcile the regional and nation-wide aspects, to improve the quality of historical knowledge. The problem of the efficiency of the contemporary school historical education is also very topical. Proceeding from the need of building of nationhood and present-day social and political conditions in the country: invasion of the part of territory, operations of the joint forces at the east boundaries, the role of itself historical school education becomes evident for education of citizens whose consciousness can be hardly manipulated through the use of misrepresentation of historical facts, his/her national identity. 


\section{ЛIТЕРАТУРА}

1. Баханов К.О. Сучасний шкільний підручник з історії К.О. Баханов. - Х.: Вид. група Основа, 2009. - 128 с.

2. Баханов К.О. Теоретико-методичні засади трансформації сучасної шкільної історичної освіти: автореф. дис. на здобуття наук. ступеня докт. пед. наук: спец. 13.00.02 Теорія та методика навчання історії / К.О. Баханов. - К., 2007. -43 c.

3. Закон України Про внесення змін до законодавчих актів з питань загальної середньої та дошкільної освіти щодо організації навчально-виховного процесу [Електронний ресурс] // Відомості Верховної Ради України. - 2010. - Режим доступу до ресурсу: https://zakon.rada.gov.ua/laws/show/2442-17.

4. Касьянов Г.В. Past continuous: історична політика 1980-х 2000-х. Україна та сусіди / Г.В. Касьянов. - К.: Laurus, Антропос-Логос-Фільм, 2018. - 420 с.

5. Навчальна програма 3 історії для 5-9 класів загальноосвітніх навчальних закладів / - К.: Міністерство освіти і науки, молоді та спорту України, 2012. - 55 с.

6. Навчальна програма з історії для 5-9 класів загальноосвітніх навчальних закладів / - К.: Міністерство освіти і нау- ки України, 2015. - 54 с.

7. Політика історичної пам'яті в контексті національної безпеки Украї ни: аналіт. доповідь / [Яблонський В.М., Лозовий В.С., Валевський О.Л., Здіорук С.І., Зубченко С.О. та ін.] / за заг. ред. В.М. Яблонського. - Київ: НІСД, 2019. $-144 \mathrm{c}$

8. Суспільствознавчі предмети. 5-11 кл.: навчальні програми, інструктивно-методичні рекомендації щодо вивчення у закладах загальної середньої освіти навчальних предметів у 2018-2019 н. p. / Укладач P.І. Євтушенко. - Х.: Вид-во Ранок, 2018. - 208 с.

9. Томаченко О.В. Політика України в галузі шкільної історичної освіти (1991-2009рр.): автореф. дис. на здобуття наук. ступеня канд. іст. наук: спец. 07.00.01 Історія України / - Луцьк, 2015. - 23 с.

10. Турченко Ф.Г. Україна - повернення історії. Генеза сучасного підручника / Ф.Г. Турченко. - К.: Генеза, 2016. $-104 \mathrm{c}$.

11. ЦДАВО України / ф. 166, оп. 17, спр. 117, 14 арк.

ЦДАВО України / ф. 166, оп. 17, спр. 85, 4 арк.

\section{REFERENCES}

1. Bakhanov K.O. Contemporary school history textbook / K.O. Bakhanov. - Kh.: Publishing group Osnova, 2009. - 128 p.

2. Bakhanov K.O. Theoretical and methodical foundations of transformation of contemporary school historical education: synopsis of pedagogical degree doctoral thesis: specialty 13.00.02 "Theory and methodology of history teaching" / K.O. Bakhanov. - K., 2007. -43 p.

3. The Act of Ukraine "On the introduction of amendments to the legislative acts on the issues of the general secondary and pre-school education as for the arrangement of teaching and educational process" [Electronic media] // Information of Verkhovna Rada of Ukraine. - 2010. - Resource is available at: https://zakon.rada.gov.ua/laws/show/2442-17.

4. Kasianov H.V. Past continuous: historical policy within the period between years of 1980 and 2000. Ukraine and its neighbors / H.V. Kasianov. - K.: Laurus, Antropos-LohosFilm, 2018. -420 p.

5. History curriculum for 5-9 grades of the general education establishments / - K.: Ministry of Education and Science, Youth and Sport of Ukraine, 2012. - 55 p.

6. History curriculum for 5-9 grades of the general education establishments / - K.: Ministry of Education and Science of Ukraine, 2015. -54 p.
7. The policy of historical memory within the context of the national security of Ukraine: the analytical report / [Yablonskyi V.M., Lozovyi V.S., Valevskyi O.L., Zdioruk S.I., Zubchenko S.O. etc.] / under general editorship of V.M. Yablonskyi. - Kyiv: NISS, 2019. - 144 p.

8. Social science disciplines. 5-11 grades: curriculums, guidelines, procedures and recommendations as for study of academic disciplines in the general secondary education establishments in 2018-2019 academic year / Author R.I. Yevtushenko. - Kh.: Publishing firm "Ranok", 2018. - 208 p.

9. Tomachenko O.V. Ukrainian policy in the field of school historical education (1991-2009 years): synopsis of thesis in support of candidature for a historical degree: specialty 07.00.01 "History of Ukraine" / - Lutsk, 2015. - 23 p.

10. Turchenko F.H. Ukraine - a history recovery. Genesis of contemporary textbook / F.H. Turchenko. - K.: Heneza, 2016. - 104 p.

11. Central State Archives Of Supreme Authorities And Governments Of Ukraine / f. 166, list of files 17, file 117, 14 sheets.

12. Central State Archives Of Supreme Authorities And Governments Of Ukraine / f. 166, list of files 17, file 85, 4 sheets. 